Journal of Life Economics

Cilt / Volume 6, Say1 / Issue 4, 2019, pp. 437-448

E - ISSN: 2148-4139

URL: https://www.ratingacademy.com.tr/ojs/index.php/jlecon

DOİ: https://doi.org/10.15637/jlecon.6.027

Araştırma Makalesi/Research Article

\title{
THE EFFECTS OF LOGISTICAL AND SUPPLY CHAIN ON THE PERFORMANCE OF SHALLOT FARMERS EAST JAVA
}

\section{La Ode Andi HERMAWAN * \& Arik PRASETYA ** \& Saparila WOROKINASIH ***}

* Master Program of Business Administration, University of Brawijaya, Malang, INDONESIA, e-mail: hermawanlaodeandi@gmail.com

ORCID ID: https://orcid.org/0000-0002-4363-6573

** Departemen of Business Administration, Faculity of Administration Sciences, University of Brawijaya, Malang, INDONESIA, e-mail: arik.p.fia@ub.ac.id

ORCID ID: https://orcid.org/0000-0002-0472-6365

*** Departemen of Business Administration, Faculity of Administration Sciences,

University of Brawijaya, Malang, INDONESIA, e-mail: saparila.fia@ub.ac.id

ORCID ID: https://orcid.org/0000-0001-6950-9954

Geliş Tarihi: 24 Eylül 2019; Kabul Tarihi: 21 Ekim 2019

Received: 24 September 2019; Accepted:21 October 2019

\begin{abstract}
This study aims to analyze and explain logistical activities in the shallot supply chain in East Java Province. Data were collected using a questionnaire from 200 shallot farmers as instruments in the study sample. Data analysis using SEM PLS method with SmartPLS 3.0 software. The results of this study indicate that transportation has a significant influence on integrative supply chains and business performance. This means that the higher the role of partners to producers to prepare transportation in the transportation process will increase integrative supply chain activities so that business performance of producers will also increase. While the integrative supply chain has a significant influence on business performance. that is, an integrated supply chain between the farmers and partners will improve the results of farmers' business performance.
\end{abstract}

Keywords: Shallots, transportation, integrative supply chain, business performance

Jel Codes: F17 C50 


\section{INTRODUCTION}

Shallot is a source of income and can provide employment opportunities to farmers so that it provides a fairly high contribution to the regional economic development, especially in the area of production centers. High market demand for shallots makes this commodity one of the leading national commodities. High consumer demand for shallots must always be fulfilled so that the business profit target can be achieved. Therefore, efforts to improve the business performance of shallot farmers are very necessary.

Improved business performance is the ability of farmers to set standards desired by customers by considering low production costs, improving product quality, inventory, reducing material costs and delivery deadlines (Tracey \& vonderembse, 2004). Improved business performance is expected to provide high profits for farmers, thus making a major contribution in meeting the needs of the community. Farmers' business performance in producing shallots has increased from year to year. This is seen from the data based on the Central Statistics Agency (www.bps.go.id,2018) where in 2013 the harvested area (Ha) was 98,937 Ha with the production of shallots amounting to $1,010,773$ tons and an increase in harvested area in 2017 was $158,172 \mathrm{Ha}$ with a production yield of $1,470,155$ tons, so that the price of shallots at the producer level (farmers) from 2013 amounted to Rp 14,801 / kg and prices continued to increase until 2017 of Rp 26,652 / kg, while the price of the consumer level fluctuated. The level of shallots productivity is still low, because the average national and local shallots productivity is only around 9-10 tons / ha, far below the production potential which is above 20 tons / ha (BPS, 2018). The low productivity of shallots is due to the lack of availability of quality seeds, limited production facilities and infrastructure, and the lack of proper implementation of specific SOPs at the location (www.bappenas.go.id).

As a commodity that is traded, of course, the yield of shallots need to be distributed in the market and industry, so there is a need for a system that regulates the supply chain management of shallots. Integrative supply chain is an activity in an organization and the activities of suppliers, customers, and other integrated supply chain members (Flynn, et al., 2010). The key factor for the success of the integrative supply chain is the cooperative relationship between different partners in the supply chain, specifically the trust and commitment of the relationship. Integrative supply chains are applied to agricultural products that have certain characteristics influenced by the production system, the nature of the product and consumers, so the logistics system must be handled specifically. In integrative supply chain activities a logistics management system is needed.

Inadequate logistics conditions will have an impact on the low competitiveness of Indonesian products, both in the domestic market and in the international market, especially for horticultural products. Perishable products such as horticultural products will be greatly affected by the logistical conditions. This will affect the quality of products and product prices at the consumer level and the accuracy of the delivery schedule and other factors of consumer concern. The process of sending shallots to harvest should consider in the choice of transportation mode.

The choice of transportation by considering distance and security will certainly create a more effective and efficient transportation movement process. Therefore, transportation management needs to be designed with due regard to these characteristics. The choice of transportation routes and safety in operations is one of the main factors that must be considered in the process of moving goods. 


\section{GRAND THEORY}

\subsection{Theory Cost Transaction Analysis (TCA)}

The agreement between the supplier and buyer considers the risks that will occur in logistics activities in the supply chain. TCA is an instrument used to decide on a transaction in supply chain activities must be done at the place of production or at the place of consumers. The grand theory in this study is Transaction cost analysis (TCA) offers a normative economic approach to determine the boundaries between producers and partners that can be used to manage all resources in the process of producing goods. (Williamson, 1975, 1985, 1996). According to Williamson, (1996) transaction cost analysis (TCA) is used in making decisions in supply chain activities. Examples are experiments in logistical activities (Maltz, 1993; Andersson, 1997; Halldorsson, 2002), relationships between suppliers and buyers (Mikkola, 2003b; Bensaou, 1999; Stuart and Mc Cutcheon, 1996), and supply chain restructuring (Croom, 2001).

\subsection{Logistics Theory}

Logistics management as part of the supply chain related to the flow of goods, services and information. The logistics process plays a key role for integration between organizations.

Prajogo \& Olhager, (2012) say that increasing logistics integration is an important factor in achieving operational benefits such as cost reduction, delays, hazards, increased sales, distribution, customer service, service levels, and customer satisfaction.

Mena and Steven in Fizzanty and Kusnandar (2012), explained some special characteristics of agricultural products including horticulture, namely:

1. Seasonal, agricultural products have a seasonal nature both in the production system and consumption.

2. Safety, nutrition and health: food products will have a direct impact on the body of someone who consumes. Therefore the factors of safety, quality, traceability become important issues.

3. Short product life and susceptibility to damage: biological properties of agricultural products lead to short life and are vulnerable to damage caused by physical or chemical

4. Impact on the environment: agricultural systems are at risk of the environment because it uses a lot of land, water, and energy.

Meanwhile Vorst, et al in Fizzanty and Kusnandar, (2012) explained the logistical characteristics of agricultural products based on actors in the supply chain, namely: farmers, traders (retailers) and industry.

\subsection{Transportation Theory}

According to Bowersox (2002), transportation provides geographical benefits to the logistics system by connecting facilities with markets. According to the theory proposed by Tracey, (2004) transportation is considered an important element in the success of logistics and supply chains. The mode of transportation assumes that the cost of shipping commodities on a particular route is proportional to the number of commodity units sent on that route (Sari, 2010: 4). Sinulingga (1999), argues that a transportation can be said to be good if the travel time is fast enough, the frequency of service is sufficient, safe or free from possible dangers and comfortable service conditions. Research conducted by Kim, et al. (2014) mentioned that this study provides an understanding of shipping goods from New Zealand choosing the right mode of transportation by interviewing 45 companies in various industries. This study presents five 
service choice criteria, namely: product maintenance, cost, timeliness, reliability and security. Research conducted by Fan, (2016) says that adjusting the speed of product transportation is considered an innovative way to get a time buffer to manage catastrophic risks in the supply chain.

\subsection{Integrative Supply Chain Theory}

The theory put forward by Kim and Narasimhan, (2002) states that integrative supply chains connect companies with customers, suppliers and other channel members by integrating relationships, activities, functions, processes, and locations. Research conducted by Suhaiza's theory, (2005) states that integrative supply chains have an impact on company performance and help local companies to invest more resources and time. It is very important for local companies to integrate their main strategies with suppliers and customers. Research conducted by Ahmad, (2005) Some companies decide on the most effective integrative method to serve suppliers and customers. Companies that choose a supplier and customer approach are expected to be more competitive and have better performance and competence. The company increasingly improves integration with suppliers and consumers, so performance is increasing both to gain trust or commitment from suppliers and consumer loyalty. So this research can be concluded that it has a significant effect on integrative supply chains on company performance.

\subsection{Theory Of Business Performance}

According to the theory proposed by Anggareni, (2009) said that performance measurement is needed to monitor and control, communicate organizational goals to functions in the supply chain, know where the position of an organization is relative to competitors and to the objectives to be achieved and determine the direction of improvement for create competitive advantage. Performance measurement is an important element in decision making in planning work effectiveness (Bhagwat and Sharma, 2007). Researchers Orsi, et al. (2017) said that measuring the business performance of farmers needs to develop basic skills and be supported in improving land and crop management, crop yields, storage and transportation.

\section{RESEARCH METHODS}

\subsection{Research Design}

This research is a type of explanatory research (explanatory research) with a quantitative approach using survey methods.

\subsection{Data Collection Method}

This research uses primary data and secondary data. Data was collected through a questionnaire to 200 respondents. The object of this research is shallots farmers from four districts in East Java Province, namely Malang Regency, Nganjuk Regency, Kediri Regency and Probolinggo Regency.

\subsection{Data Analysis}

Data analysis using the Structural Equation Modeling (SEM) method is one of the methods currently used to cover weaknesses in the regression method. To analyze the data the researcher used the SEM PLS method with SmartPLS 3.0 software. 


\section{FINDING}

In the inferential statistical analysis of this study there are three stages namely

\subsection{Evaluation of Measurement Model (Outer Model)}

Outer Analysis This model specifies the relationship between latent variables with indicators or items. It can be said that the outer model defines how each item relates to the latent variable. The following items are measured that are associated with latent variables.

Table 1. Variables And Items

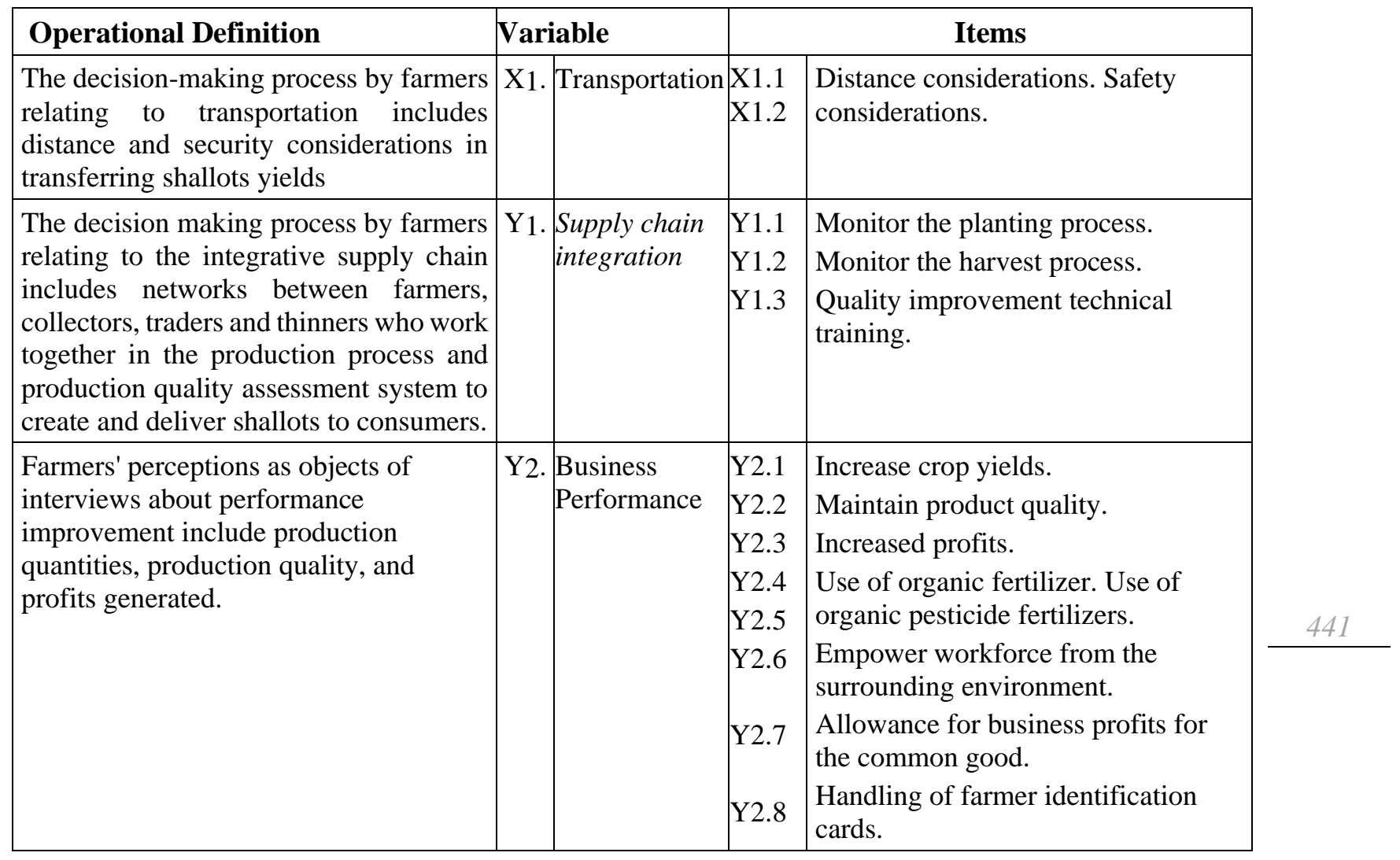

Figure 1. Outer Model Analysis

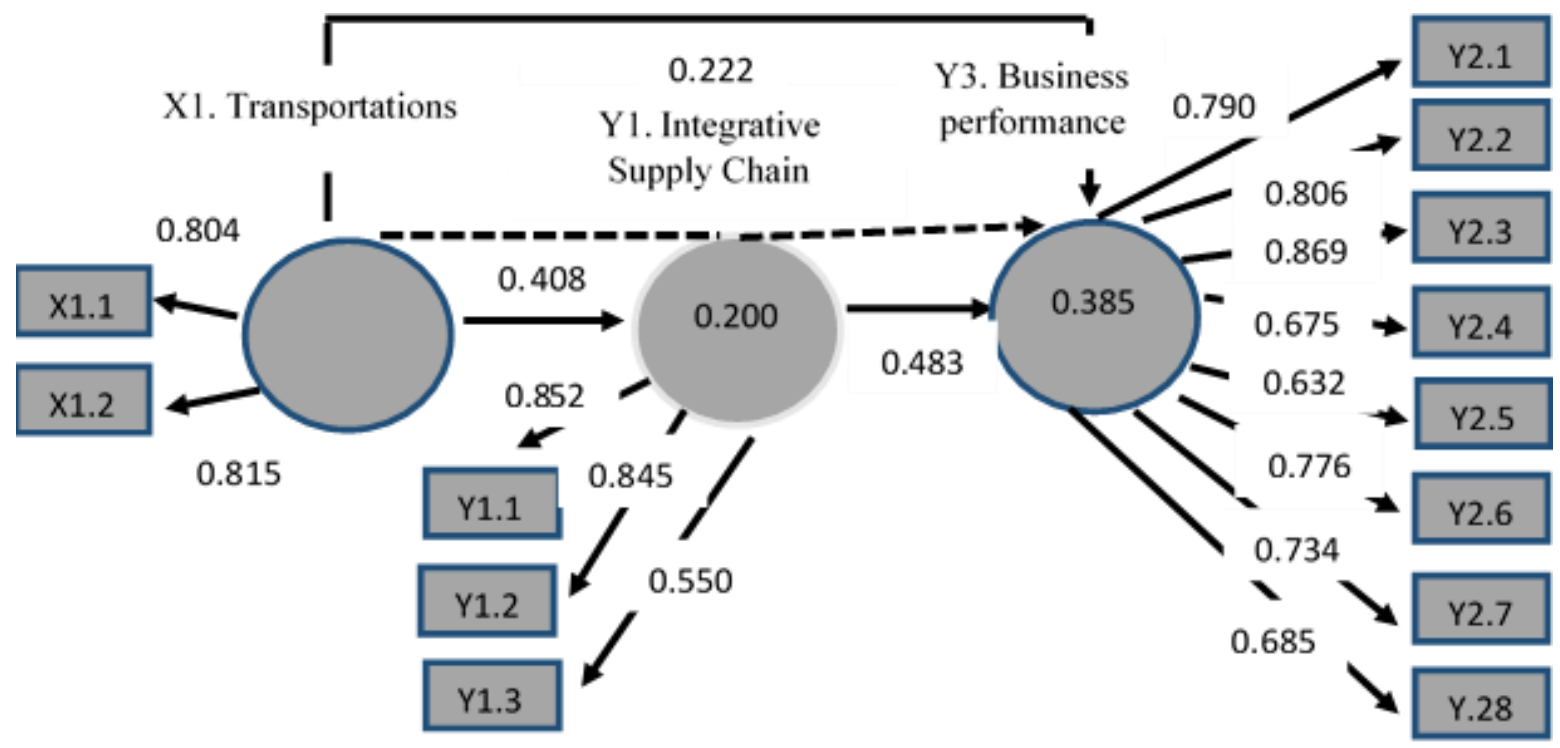

Source: SmartPLS 3.0 output 
In outer mode measurement has three criteria, namely discriminant validity, convergent validity, and composite reliability. There are three construct variables used in this study, namely transportation, integrative supply chain, and business performance.

\subsection{Evaluation of Structural Model (inner Model)}

Inner model analysis / structural model analysis is carried out to ensure that the structural model that is constructed is robust and accurate. Evaluation of inner models can be seen from several indicators / items.

Figure 2. Analysis of the inner model

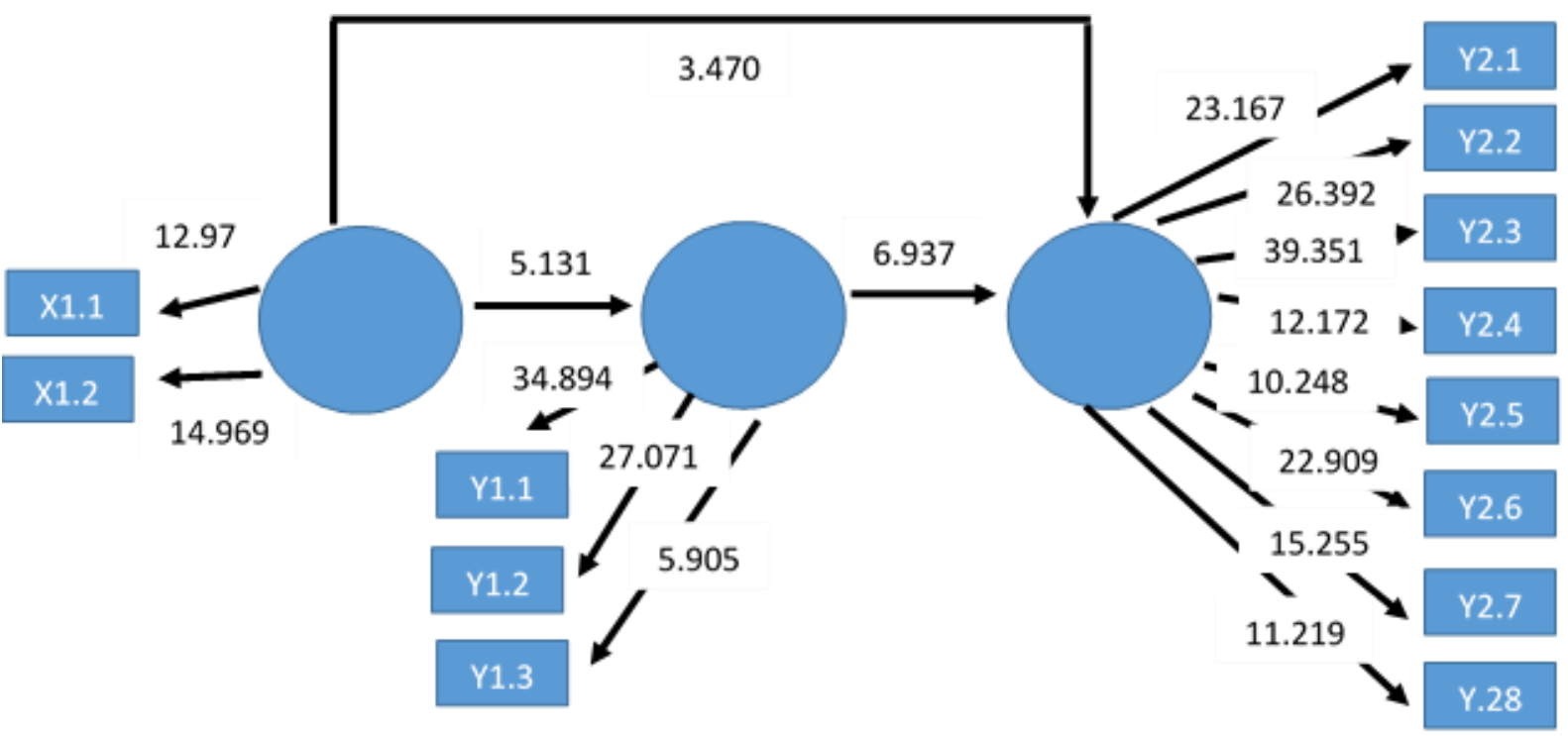

Source: SmartPLS 3.0 output

Structural model testing (inner model) is done to measure the relationship between variables using SmartPLS 3.0 software. This test is carried out to determine through R-Square contained in endogenous (dependent) variables.

\subsection{Hypothesis Testing Results}

The findings of the research hypothesis testing using bootstrapping from SmartPLS analysis are as follows:

Table 2. Hypothesis Testing Results

\begin{tabular}{|l|l|l|l|l|l|l|}
\hline & $\begin{array}{l}\text { Original } \\
\text { Samples } \\
(\mathbf{O})\end{array}$ & $\begin{array}{l}\text { Averages } \\
\text { Sample } \\
\text { (M) }\end{array}$ & $\begin{array}{l}\text { Standard } \\
\text { Deviation } \\
\text { (STDEV) }\end{array}$ & $\begin{array}{l}\text { T Statistics } \\
(\mid \mathbf{O} / \mathbf{S T D E V})\end{array}$ & $\begin{array}{l}\text { P } \\
\text { Values }\end{array}$ & Information \\
\hline $\begin{array}{l}\text { Transportation -> } \\
\text { Integrative Supply } \\
\text { Chain }\end{array}$ & 0,408 & 0,414 & 0,066 & 6,174 & 0,000 & Significant \\
\hline $\begin{array}{l}\text { Transportation -> } \\
\text { Business performance }\end{array}$ & 0,222 & 0,224 & 0,068 & 3,282 & 0,001 & Significant \\
\hline $\begin{array}{l}\text { Integrative Supply } \\
\text { Chain } \\
->\text { Business } \\
\text { performance }\end{array}$ & 0,483 & 0,487 & 0,069 & 7,035 & 0,000 & Significant \\
\hline $\begin{array}{l}\text { Transportation -> } \\
\text { Rantai pasok integratif } \\
->\text { Business } \\
\text { performance }\end{array}$ & 0,197 & 0,202 & 0,046 & 4,303 & 0,000 & Significant \\
\hline
\end{tabular}

Source: SmartPLS 3.0 output 
The results of the influence of hypothesis testing are as follows:

1. Testing the H1 Hypothesis

The results of testing the influence of Transportation (X1) on the Integrative Supply Chain (Y1) can be seen in table 1 showing a path coefficient of 0.408 which means that the influence of transportation (X1) on the integrative supply chain (Y1) with a t-statistic of 6.174 and $\mathrm{p}$-value 0,000 , then the decision is $\mathrm{H} 1$ accepted, meaning the hypothesis that transportation has a significant effect on the integrative supply chain is accepted.

\section{H2 Hypothesis Testing}

The results of testing the influence of Transportation (X1) on Business Performance (Y2) can be seen in table 1 showing the path coefficient of 0.222 which means that the influence of transportation (X1) on business performance (Y2) with a t-statistic of 3.282 and a p-value of 0.001 , then the decision is $\mathrm{H} 1$ accepted, meaning the hypothesis that transportation $(\mathrm{X} 1)$ has a significant effect on business performance (Y2) is accepted.

\section{Hypothesis Testing $\mathrm{H} 3$}

The test results of the influence of the integrative supply chain (Y1) on Business Performance (Y2) can be seen in table 1 shows the path coefficient of 0.483 which means that the influence of the integrative supply chain (Y1) on business performance (Y2) with a tstatistic of 0.483 and the $\mathrm{p}$ value -value of 7.035 , then the decision is $\mathrm{H} 1$ accepted, meaning the hypothesis that the integrative supply chain (Y1) has a significant effect on business performance (Y2) is accepted.

\section{Hypothesis testing $\mathrm{H} 4$}

The results of testing the influence of Transportation (X1) indirectly on Business Performance (Y2) through the Integrative Supply Chain (Y1) can be seen in table 1 showing the influence of transportation (X1) on business performance (Y2) through the interrelative supply chain (Y1) the indirect path coefficient is 0.197 with a t-statistic value of 4.303 . The $t-$ statistic value shows that the t-statistic value is greater than t-table $(1,960)$. As well as a p-value of 0.00 the decision $\mathrm{H} 6$ is accepted. The P-value obtained indicates a value of less than 0.05 so that it shows that the integrative supply chain (Y1) has a significant influence in mediating the effect of transportation (X1) on business performance (Y2).

\section{DISCUSSION}

\subsection{Effects Of Transportation (X1) On Integrative Supply Chains (Y1)}

Transportation plays an important role in the integrative supply chain system in moving the availability of goods from the original location to the destination location. In the selection of transportation there are several things that must be considered, namely the type, nature of the product, vehicle capacity, timeliness and type of handling properly so that the costs incurred can be as minimal as possible and increase profits, in order to be efficient in suppressing intransit inventory and increasing security so reduce the risk of damage and loss in the distribution process.

Hypothesis testing The value of the Transport variable (X1) to the integrative supply chain that is transportation (X1) has a positive and significant effect on the integrative supply chain variable (Y1). This study looks at the relationship made by farmers and traders for the selection of transportation facilities used to transport shallots. In the selection of transportation facilities the majority of partners (traders) prepare themselves or rent other vehicles but the vehicle costs are usually borne by partners (traders) because farmers do not want to bear the risk of damage to shallots when transporting unless the price of shallotss goes down and there 
is a distribution of transportation costs. By using a cost sharing system when the price of shallots goes down, no party will be disadvantaged because they have to bear the joint costs.

This research is supported by a theory put forward by Bowersox (2002), stating that transportation provides geographical benefits to the logistics system by connecting facilities with markets. In the transportation system, many choices must be made to obtain the convenience and smoothness of transportation of goods, including the mode of transportation or type of vehicle that is suitable for the situation (Rushton, et al. 2010). While another theory put forward by Tracey (2004), states that transportation is considered an important element in the success of logistics and supply chains.

The research that has been done is in line with Rockpoint's research in the research of Kim, et al. (2014) said that in his research presented five criteria for transportation service choices, namely: product maintenance, cost, timeliness, planning and security. Timeliness is said to be the most important service factor, followed by product maintenance and safety. This means that in the selection of transportation modes when shipping or taking goods adjusted to the level of need and minimize risk.

The key factor for the success of integrative supply chains is the cooperative relationship between different partners in the supply chain, in particular, trust and commitment to relationships especially in terms of transportation (Handfield and Bechtel, 2002; Beth, et al. 2003; Kwon and Suh, 2005).

Another study conducted by Yun Yun (2014), said to study the development of rural supply chains to support agricultural businesses by building effective supply chains starting from supplier farmers, distributors and retailers. There must be cooperation with various parties involved in the supply chain activities. The results show that the logistics management of agricultural products cannot stand alone but must be managed together with the components of the supply chain so that the competitive advantage of Indonesian agricultural products can be superior to other countries. Transportation must meet the requirements specified in the customer service policy such as time requirements (arrive before), time conditions (arrive after / depart before), volume requirements (cubic or weight sent between each origin and destination), frequency requirements (shipping per time period) and minimal damage on the route.

\subsection{Effects Of Transportation (X1) On Business Performance (Y2)}

Testing the influence of transportation (X1) on business performance (Y2) there is a significant relationship because the transportation used to transport the shallots harvest is prepared from traders, this can affect the improvement of farmer's business performance.

This research is supported by a theory put forward by Bowersox (2002), stating that transportation provides geographical benefits to the logistics system by connecting facilities with markets. In a network of facilities, transportation is a link in a business performance. In designing a logistics system in a business, it is important to establish a balance between transportation costs and the quality of service. Research conducted in line with the results of research conducted by Tracey (2004), that there is a positive influence between transportation and business performance.

Another study conducted by Simkova (2015), states that transportation performance can be formed through Performance Indicators that help organizations in determining and measuring the progress of business objectives. Performance Indicators are measurements that can be measured and agreed upon in advance that reflect critical success factors in a business. If performance is specific and simple, it can be easily communicated so that it is easy to use and easy to understand. Quality is a very important indicator to keep customers in the company. This affects the performance and economic results of the company. When the company has a 
competitive advantage, it means the company is able to meet customer requirements as well as being able to meet customer desires. If the customer feels dissatisfied with the company's service, the customer can say dissatisfaction with the company's service so that it can affect other customers as a result the company will lose revenue and lose customers.

According to the theory proposed by Anggareni (2009), it states that business performance measurement is needed to monitor and control, communicate organizational goals to functions in the supply chain, know where the position of an organization is relative to competitors and to the objectives to be achieved and determine the direction of improvement to create competitive advantage.

\subsection{Effects Of Integrative Supply Chains (Y1) On Business Performance (Y2).}

Testing the value of the integrative supply chain variable (Y1) on business performance (Y2) that there is a significant relationship between the integrative supply chain variable (Y1) and the business performance variable (Y2). The influence of integrative supply chains (Y1) on business performance (Y2) is significant because producers (farmers) and traders collaborate to establish good relationships in order to create a mutually beneficial integrative supply chain. This means that an increasingly integrated integrative supply chain will improve the business performance of producers (farmers). This research is in line with the theory put forward by Kim and Narasimhan, (2002) stating that integrative supply chains connect companies with customers, suppliers, and other channel members by integrating relationships, activities, functions, processes, and locations.

Research conducted in line with research conducted by Suhaiza (2005), says that integrative supply chains impact company performance, will help local companies get ready to invest more resources and time. It is very important that local companies start to become agile and learning organizations so that local companies continue to integrate their main strategies with suppliers and customers. According to the results of research conducted by Suhaiza (2005), said that the key factor for the success of integrative supply chains is the cooperative relationship between different partners in the supply chain, specifically, trust and commitment of the relationship.

This research is also in line with research conducted by Ahmad, (2005). Research conducted by Ahmad (2005), said that the competition was carried out not only to see competition between companies but also to see the supply chain applied by each company. Some companies decide on the most effective integrative method to serve suppliers and customers. Choosing a supplier and customer approach is expected to be more competitive and have better performance and competence. The more a company increases integration with suppliers and consumers, the performance will improve both to gain trust or commitment from suppliers and consumer loyalty. The pattern of integration affects company performance. The more the company integrates with suppliers and consumers, the performance increases both the company gets the trust or commitment from suppliers and consumer loyalty.

The theory put forward by Anggareni (2009), says that performance measurement is needed to monitor and control, communicate organizational goals to functions in the supply chain, know where the position of an organization is relative to competitors and to the objectives to be achieved and determine the direction of improvement for create competitive advantage.

\subsection{Indirect Effects Between Transportation (X1), Integrative Supply Chain (Y1) And Business Performance (Y2).}

Based on the results of data analysis conducted using SmartPLS 3.0 software, there is an indirect significant effect between the variables of Transportation (X1), integrative supply chain (Y1) and business performance (Y2). Based on this, the integrative supply chain variable 
(Y1) can be stated as a mediating or intervening variable meaning that the integrative supply chain has a major influence on transportation in improving business performance.

Based on the results of the path coefficient value of each relationship between variables shows that there is an indirect relationship between variables (Transportation X1) to business performance (Y2) mediated by the integrative supply chain (Y1) is having a significant effect. This means that integrative supply chains play an important role indirectly to increase the influence of transportation in improving business performance.

In this research, transportation used for the process of transporting shallot harvest is prepared from traders so that the costs are fully borne by the trader with the aim of minimizing costs and maximizing the overall value generated to meet the needs and demands of customers. So it can be concluded that the integrative supply chain has a significant influence in mediating transportation in improving farmers' business performance. The better the transportation system owned by partners (traders) will improve business performance.

According to the theory put forward by Bowersox (2002), said that in a network of facilities, transportation is a chain of connecting a business. In designing a logistics system, a balance must be established between transportation costs and the quality of service (Bowersox, 2002). This research is in line with research conducted by In Tracey, (2004) explained that there is a positive influence between transportation and business performance. Another study conducted by Fan (2016), said that about the modes of transportation for the final product significantly impact the supply chain costs, the mode of transportation for long-distance transportation of products significantly impacts the supply chain flexibility.

According to the theory put forward by Narasimhan \& Ajay, (2001) said that integrative supply chains can also be seen from the surrounding dimensions, namely consumer integration, information integration, distribution and logistics integration, supplier integration and purchase integration. Integrative supply chains combine information integration, logistics integration, distribution integration, purchase integration, internal integration, supplier integration, customer integration, process integration and product integration (Das, et al. 2006).

\section{CONCLUSIONS AND LIMITATIONS}

\subsection{Conclusion}

This study aims to analyze and explain logistical activities in the shallot supply chain in East Java Province. The results of this study indicate that transportation has a significant influence on integrative supply chains and business performance. This means that the higher the role of partners to producers to prepare transportation in the transportation process will increase integrative supply chain activities so that business performance of producers will also increase. While the integrative supply chain has a significant influence on business performance. That is, an integrated supply chain between the farmers and partners will improve the results of farmers' business performance.

\subsection{Limitations}

This data has limitations on research respondents based on education and research respondents only focus on the perspective of shallots farmers. This limitation causes limitations to obtain information shallots supply chain in East Java Province.

\section{CONTRIBUTION}

This research contributes to farmers in improving relations between partners for the use of logistics in supply chain activities to improve business performance in the field of horticulture, especially shallots. 


\section{REFERENCES}

ABDILlAH, W. \& DAN HARTONO, J. (2015). Partial Least Square (PLS): Alternatif Structural Equation Modeling (SEM) dalam Penelitian Bisnis. Yogyakarta

AKHMAD I.S. \& BAMBANG S., (2005). Integrasi Supply Chain Dan Dampaknya Terhadap Performa Perusahaan. BENEFIT, Vol. 9, No. 1. Surakarta

ANGGARENI, W. (2009). Pengukuran Kinerja Pengelolaan Rantai Pasok Pada PT.Crown Closures Indonesia.Jakarta: Universitas Gunadarma.

BHAGWAT R. \& SHARMA MK. (2007). Performance measurement of Supply Chain Management: A balanced scorecard approach. Comput Ind Eng. 53 (2007) 43-62.doi: 0.1016/j.cie.2007.04.001.

BOWERSOX, D. J, CLOSS, D. J. \& COOPER, M. B., (2002). Supply Chain Logistics Management “. Irwin/ MC Graw Hill series.

DAN KUSNANDAR FIZZANTY, T. (2012). Pengelolaan Logistik dalam Rantai Pasok Produk Pangan Segar Di Indonesia. Jakarta. Pusat Penelitian Perkembangan Iptek-Lembaga Ilmu Pengetahuan Indonesia

DAS, A., NARASIMHAN, R., \& TALLURI, S. (2006). Supplier Integration-Finding An Optimal Configuration", Journal of Operations Management, Vol. 24 No. 5, pp. $563-$ 582.

FAN, Y., SCHWARTZ, F., \& VOß, S. (2017). Flexible supply chain planning based on variable transportation modes. International Journal of Production Economics, 183, 654-666. Doi:10.1016/j.ijpe.2016.08.020

FLYNN, B.B., HUO, B. \& ZHAO, X. (2010). The Impact Of Supply Chain Integration On Performance: A Contingency and Configuration Approach. Journal of Operations Management, 28, 58-7.

Gula Merah Pada Ud Sari Bumi Raya Menggunakan Model Transportasi Dan Metode Least Cost.

HANDFIELD, R.B., \& BECHTEL, C. (2002). The Role of Trust And Relationship Structure In Improving Supply Chain Responsiveness, Industrial Marketing Management, Vol. 31 No. 4, pp. 367-382.

KIM, H.-C., NICHOLSON, A., \& KUSUMASTUTI, D. (2014). Freight Transport Mode Choice and Mode Shift in New Zealand: Findings of a Revealed Preference Survey. Sustainable Logistics, 165-192.doi:10.1108/s2044-994120140000006007

KIM, S. W., \& NARASIMHAN, R. (2002). Information System Utilization In Supply Chain Integration Efforts. International Journal of Production Research, 40(18), 4585-4609.

LAMBERT, D. M. \& STOCK, J. R. (1993). Strategic Logistics Management “3 rd ed., Richard D Irwin. Inc

ORSI, L., DE NONI, I., CORSI, S., \& MARCHISIO, L. V. (2017). The role of collective action in leveraging farmers' performances: Lessons from sesame seed farmers' collaboration in eastern Chad. Journal of Rural Studies, 51, 93-104. Doi:10.1016/j.jrurstud.2017.02.011

PRAJOGO D.,\& OLHAGER, J.. (2012). Supply chain integration and performance: The effects of longterm relationships, information technology, and sharing, and logistics integration. International Journal of Production Economic, 135, 514-522. 
RUSHTON, A., CROUCHER, P., \& BAKER, P. 2010. The Handbook of Logistics And Distribution Management 4th Edition. London: Kogan Page Limited.

SIMKOVA, I.., et al. (2015). Measuring The Quality Impacts On The Performance In Transport Company. Volume 10 Issue 3. DOI: 10.21307

SINULINGGA, B.D. (1999). Pembangunan Kota Tinjauan Regional dan Lokal. Jakarta: Pustaka Sinar Harapan.

SLACK, N., CHAMBERS, S. \& JOHNSTON, R. (2001). Operations Management, 3rd ed., Prentice-Hall, Harlow.

TRACEY, M.. (2004). Transportation Effectiveness and Manufacturing Firm Performance. The International Journal of Logistics Management, Vol. 15 Iss 2 pp. 31 - 50

www.bappenas.go.id. Desember $5^{\text {th }}$

www.bps.go.id.2018. January $11^{\text {th }}$

YUN YUN DAN KURNIAWA, A. (2014). Supply Chain Logistik Dalam Kaitannya Dengan Ketahanan Pangan Di Pedesaan. Proseding Seminar Bisnis \& Teknologi ISSN: 24076171. Cimahi

ZAILANI, S. \& RAJAGOPAL, P. (2005). Supply chain integration and performance: US versus East Asian companies, Supply Chain Management: An International Journal, Vol. 10 Issue: 5, pp.379-393,https://doi.org/10.1108/13598540510624205 